\title{
Foix-Alajouanine syndrome mimicking a spinal cord tumor
}

\author{
Renan Salomão ${ }^{1 *}$, Nathalie Henriques Silva Canêdo ${ }^{2}$, Guilherme P. Abrão ${ }^{3}$, Carlos Lima $^{1}$, Marcus André Acioly 1,4 \\ ${ }^{1}$ Division of Neurosurgery, Universidade Federal do Rio de Janeiro (UFRJ), Rio de Janeiro, RJ, Brazil \\ ${ }^{2}$ Division of Neuropathology, UFRJ, Rio de Janeiro, Brazil \\ ${ }^{3}$ Division of Neuroradiology, Universidade Federal Fluminense (UFF), Niterói, RJ, Brazil \\ ${ }^{4}$ Division of Neurosurgery, UFF, Niterói, RJ, Brazil
}

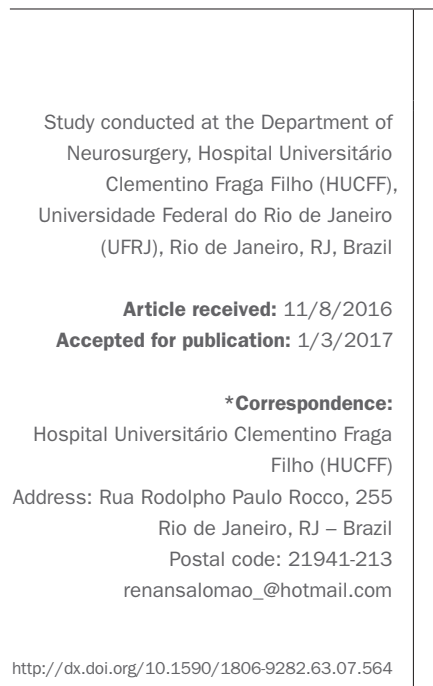

\section{SUMMARY}

Subacute necrotizing myelopathy (SNM) or Foix-Alajouanine syndrome is a rare disease characterized by progressive neurological dysfunction caused by a spinal dural arteriovenous fistula (AVF). Radiological diagnosis is usually suspected when there is intramedullary nonspecific enhancement and perimedullary flow voids. Ring-enhancement is rarely reported in the scope of AVF, which poses a diagnostic challenge and raises the suspicion of a spinal cord tumor. In such situations, biopsy can be required and delay proper diagnosis. We report the case of a patient with SNM, who underwent biopsy on the assumption of it being a spinal cord tumor.

Keywords: dural arteriovenous fistula, Foix-Alajouanine syndrome, spinal cord glioma, subacute necrotizing myelopathy.
Subacute necrotizing myelopathy (SNM) is an uncommon disease characterized clinically by progressive neurological dysfunction. ${ }^{1,2}$ In most of the patients, it is caused by a spinal dural arteriovenous fistula (dAVF), also known as Foix-Alajouanine syndrome. ${ }^{1,3} \mathrm{dAVF}$ leads to spinal venous hypertension and infarction, as the pathological end-stage of the disease. ${ }^{1}$ Such acute/subacute deterioration occurs in $14.8 \%$ of the patients. ${ }^{4}$

This 71-year-old lady was admitted to our department after suffering from a progressive neurological deterioration of the lower limbs, as well as sphincter dysfunction over the last two years. Five days before admission, the patient was affected by severe lumbar pain, which was followed by rapid severe paraparesis. Imaging revealed an expansive lesion at D12-L1 with ring-enhancement and subtle perimedullary flow voids (Figure 1). The patient underwent biopsy of the lesion, on the assumption of it being a spinal cord tumor. Initially, it was misinterpreted as a high-grade glioma on frozen specimens, but final histological analysis revealed the typical findings of SNM. Superselective spinal angiography confirmed dAVF diagnosis (Figure 1), and the patient was taken to surgery for definitive treatment.
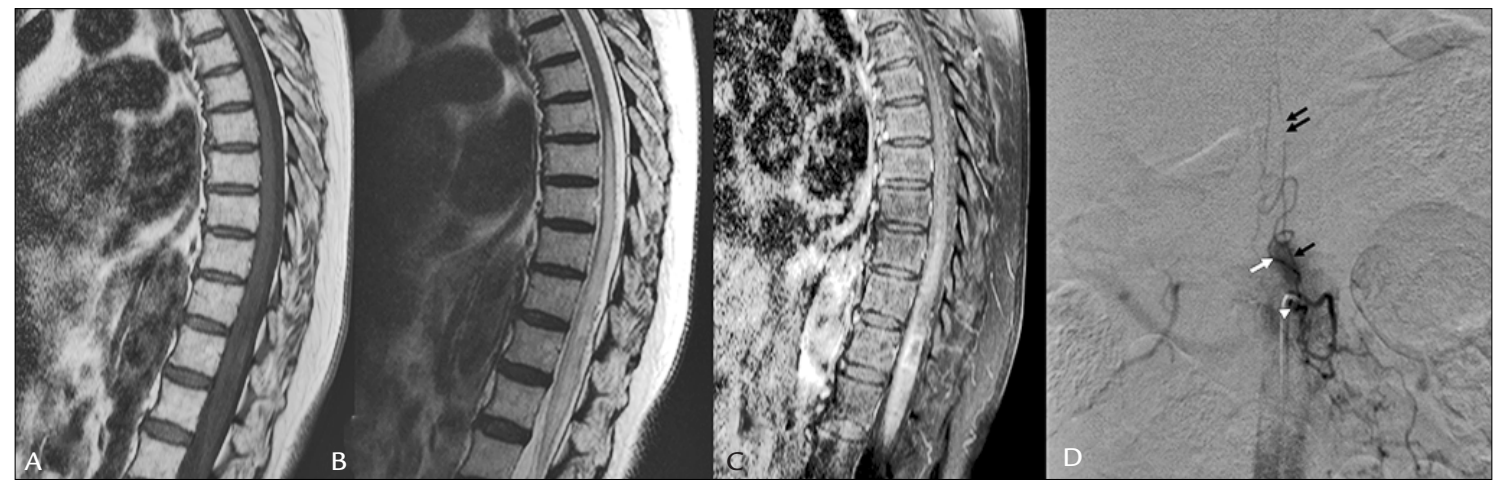

FIGURE 1 Sagittal T1- (A), T2- (B), and T1-weighted with gadolinium enhancement and fat suppression (C) showed diffuse fusiform enlargement of the spinal cord up to the level of the conus medullaris together with ring-like enhancement at D12-L1. A subtle serpentine pattern of flow voids was observed on T2-weighted images (B). In D, superselective angiogram in frontal view revealed enlarged vessels on the left side of the spinal canal at the level of D12 (white arrow head), as well as the Adamkiewicz artery (black arrows) and the draining vein (white arrow). 
SNM imaging in the scope of dAVFs typically shows focal enlargement of the spinal cord, isointense signal on T1-weighted images, intramedullary increased signal and perimedullary flow voids on T2-weighted images, as well as nonspecific enhancement. ${ }^{5}$ Ring-enhancement is rarely reported, ${ }^{1}$ which poses a diagnostic challenge and raises the suspicion of a spinal cord tumor. In such situations, biopsy may be required and delay proper diagnosis.

\section{Conflict of interest}

The authors declare no conflict of interest.

\section{Resumo}

Síndrome de Foix-Alajouanine simulando um tumor intramedular espinal

Mielopatia necrotizante subaguda (MNS) ou síndrome de Foix-Alajouanine é uma doença rara que se caracteriza por disfunção neurológica progressiva causada por uma fístula arteriovenosa espinal dural. O diagnóstico radiológico é comumente suspeitado quando aparece captação não específica de contraste e de artefatos de fluxo (flow voids) perimedulares. Raramente, a captação de contraste exibe o aspecto em anel, constituindo um grande desafio diagnóstico. Nesses casos, o principal diagnóstico diferencial é um tumor intramedular, e os pacientes são encaminhados para biópsia da lesão, atrasando o diagnóstico definitivo. Relatamos o caso de uma paciente com MNS, a qual foi submetida à biópsia da lesão em virtude de suspeita de tumor intramedular.

Palavras-chave: fístula arteriovenosa espinal dural, síndrome de Foix-Alajouanine, tumor de medula espinal, mielopatia necrotizante subaguda.

\section{References}

1. Mirich DR, Kucharczyk W, Keller MA, Deck J. Subacute necrotizing myelopathy: MR imaging in four pathologically proved cases. AJNR Am J Neuroradiol. 1991; 12(6):1077-83.

2. Kim RC. Necrotizing myelopathy. AJNR Am J Neuroradiol. 1991; 12(6):1084-6.

3. Ferrell AS, Tubbs RS, Acakpo-Satchivi L, Deveikis JP, Harrigan MR. Legacy and current understanding of the often-misunderstood Foix-Alajouanine syndrome. Historical vignette. J Neurosurg. 2009; 111(5):902-6.

4. Rosenblum B, Oldfield EH, Doppman JL, Di Chiro G. Spinal arteriovenous malformations: a comparison of dural arteriovenous fistulas and intradural AVM's in 81 patients. J Neurosurg. 1987; 67(6):795-802.

5. Dumont AS, Oldfield EH. Spinal vascular malformations. In: Richard Winn H, editors. Youmans neurological surgery. 6. ed. Philadelphia: Elsevier Saunders; 2011. v. 4, p. 4167-202. 